\title{
Uranium exploration in South Greenland
}

\section{Ashlyn Armour-Brown, Tapani Tukiainen, Bjarne Wallin, Colin Bradshaw and C. Henry Emeleus}

Following the promising reconnaissance results in 1979 and the finding of uranium and niobium mineralisation in 1980 (Armour-Brown et al., 1981), the Syduran project was extended under the Ministry of Energy's Research Programmes of 1981 and 1982 which has allowed one further field season for following up some of the more promising anomalies and uranium mineral occurrences.

The main objectives of this season's work was firstly to initiate the detailed mapping of the $\mathrm{U}-\mathrm{Nb}$ mineralised zones and the geology of the Motzfeldt Centre and secondly to locate the source of as many geochemical and gamma-spectrometer anomalies as possible which occur in the Granite Zone and Migmatite Complex of South Greenland (fig. 21), at the same time as evaluating the appropriate exploration techniques in the different environments.

\section{Motzfeldt Centre}

The geological mapping of the Motzfeldt Centre is being carried out in collaboration with Colin Bradshaw who is preparing a Ph.D. thesis on the petrology of the centre under the

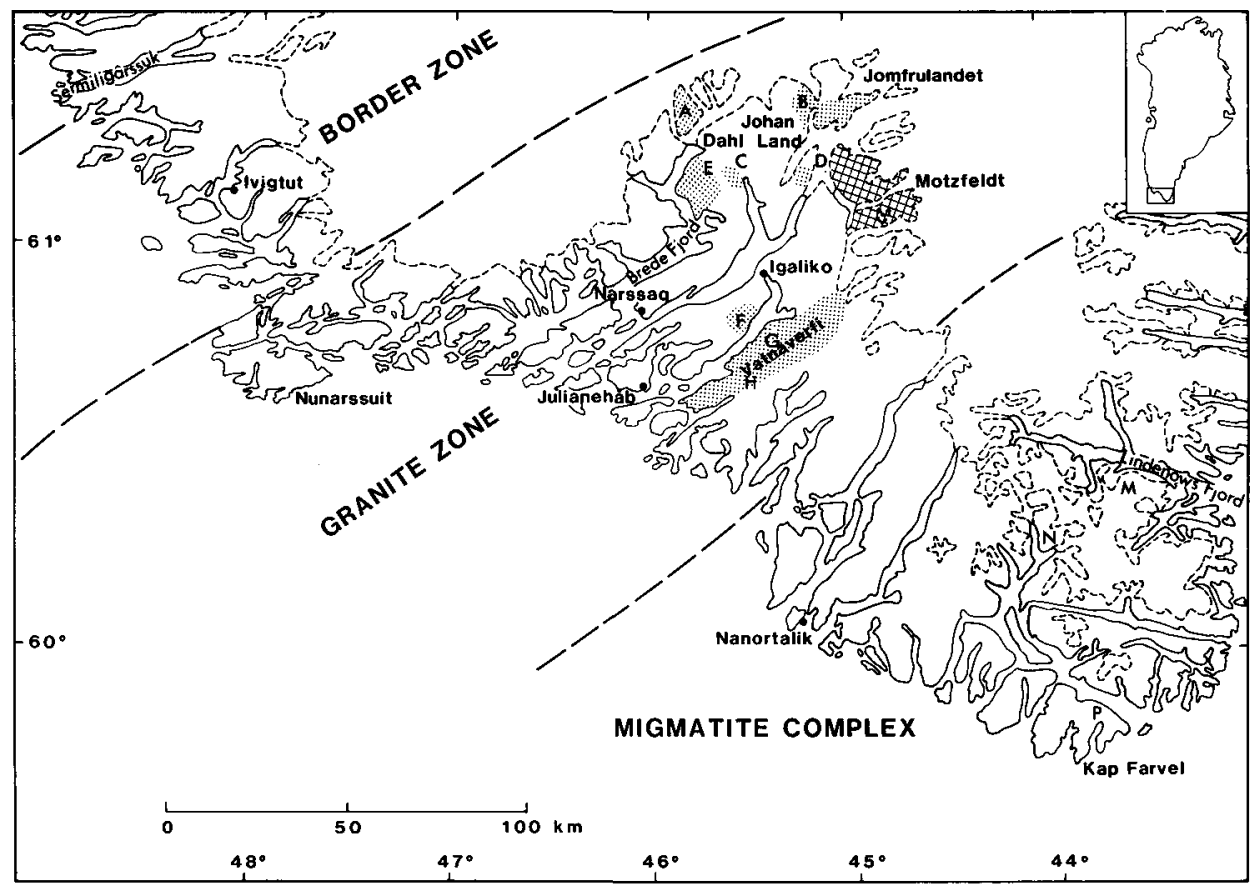

Fig. 21. Map of South Greenland showing the desribed locations. 


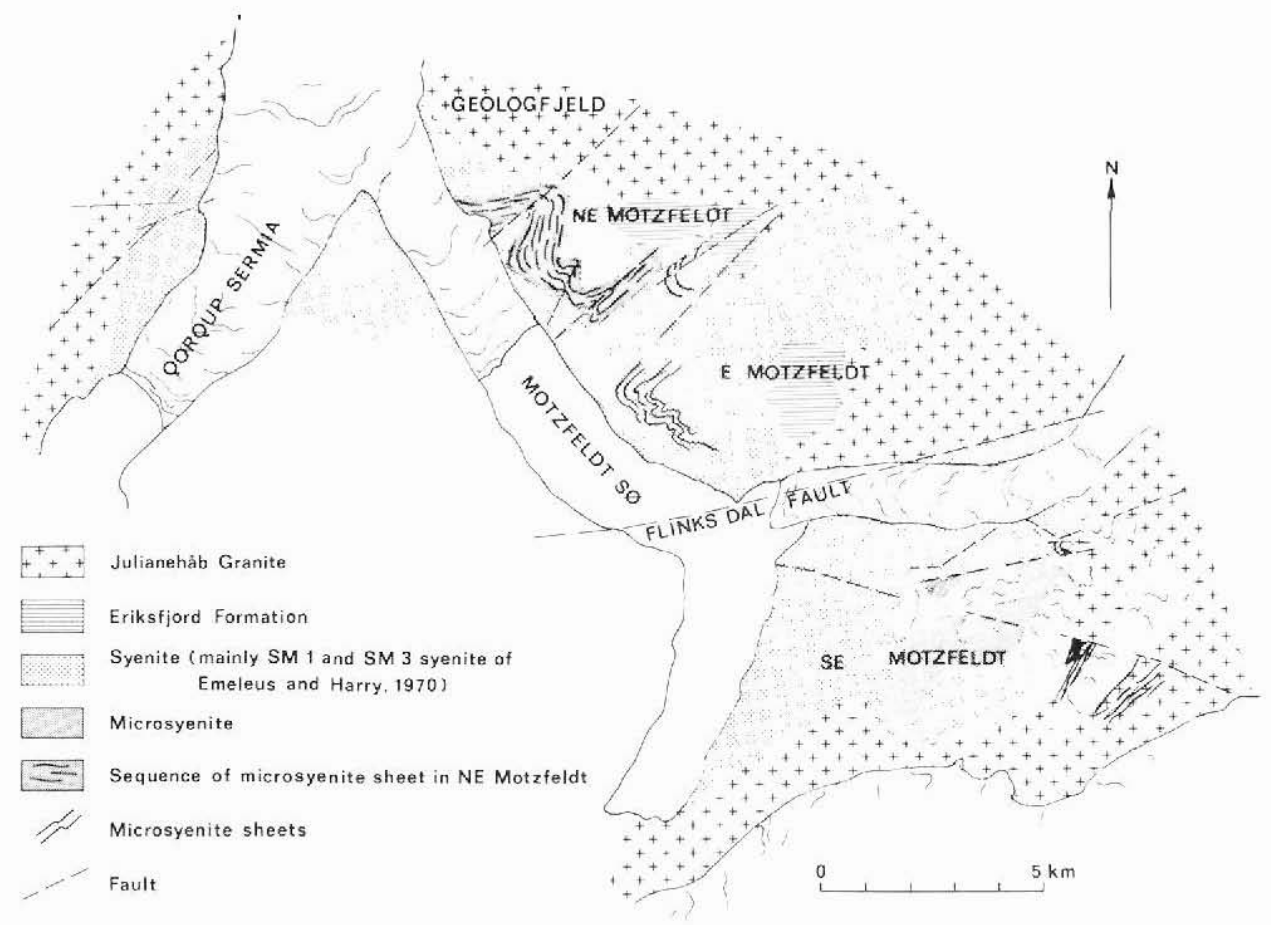

Fig. 22. Geological sketch map and locations in the Motzfeldt Centre.

supervision of Henry Emeleus at the University of Durham. The U-Nb mineralisation was mapped by Tapani Tukiainen using the helicopter-borne gamma-spectrometer equipment developed at Risø National Laboratory supplemented by ground sampling and observations. New, excellent 1:50000 aerial photographs and 1:10000 contoured orthophoto maps provided a good basis for collating this data.

The Motzfeldt Centre is one of four alkaline igneous centres belonging to the Igaliko nepheline syenite complex (Emeleus \& Harry, 1970). The intrusions within the centre show a range of compositions from syenogabbro to lujavrite (Jones, 1981) and host considerable radioactive occurrences (Tukiainen, 1981).

Most of the previously established syenite units and their age relationships have been confirmed and the original syenite terminology of Emeleus \& Harry (1970) and Jones (1981) is retained. Some important observations are outlined below.

South-east Motzfeldt. In south-east Motzfeldt (fig. 22) the syenite SM 3 occurs not in one solid arcuate band (Emeleus \& Harry, 1970, plate IV), but as a number of narrow, individual, near vertical intrusions with a range of widths of approximately 4 to $20 \mathrm{~m}$ which cuts the syenite units SM 1 and SM 2. This belt of the SM 3 syenite follows approximately the SM 1 -SM 2 contact. The individual members of this unit are petrographically very similar and probably emerge from a common source at some shallow depth. Most of the exposed ground in the eastern part of south-east Motzfeldt is composed of a suite of peralkaline microsyenite sheets sandwiched between medium grained syenite which resembles SM 1. These sheets, 
which are up to at least $200 \mathrm{~m}$ thick, also extend far into the basement granite where they thin out. Evidence of roof collapse was obtained near the eastern margin of the centre where large rafts (from 5 to $20 \mathrm{~m}$ thick) of Gardar supracrustal rock composed of agglomerate, tuff and sandstone are seen enclosed by the microsyenite. The microsyenite probably welled up and filled the cavity left by the foundered crust. The presence of rafts confirms the previous existence of Gardar supracrustal rocks over this part of the centre.

East and north-east Motzfeldt. The broad belt of SM 3 syenite in east and north-east Motzfeldt (Emeleus \& Harry, 1970, Plate IV) is composed of a complex suite of syenites. Although characterised by a well developed feldspar lamination the rocks vary in grain size and texture. The SM 1 syenite, similarly, is remarkably variable in texture and composition containing some mappable units in east Motzfeldt. The SM 3 and SM 1 syenite units are truncated by a suite of peralkaline microsyenite sheets which are most abundant in north-east Motzfeldt ranging from 1 to $10 \mathrm{~m}$ in thickness. Within the unit as a whole the frequency of the sheets increases upwards until they make up over $80 \%$ of the bulk and comprise a thickness of greater than $400 \mathrm{~m}$. In east Motzfeldt they are subhorizontal but in north-east Motzfeldt they strike approximately E-W and dip 25 to $45^{\circ}$ north. The roof zone of the intrusion is exposed in north-east Motzfeldt where the Julianehåb Granite overlies a homogeneous leucocratic syenite (SM 1?). The planar syenite-granite contact dips approximately $30^{\circ}$ to the north.

Faulting and its effect on the distribution of lithology. The Motzfeldt Centre is dissected by two sets of vertical or steeply dipping faults, one striking NE-SW and another one approximately E-W. The most dramatic dislocations, both vertically and laterally, took place along the E-W striking sinistral faults. The lateral displacement along the Flinks Dal fault is estimated to be $6 \mathrm{~km}$. The magnitude of the vertical movements is not known but on the basis of the lithological characteristics, lack of roof rocks and steep external contacts, east Motzfeldt is probably an upthrown block.

Airborne gamma-spectrometric survey and radioactive mineralisation. The helicopterborne gamma-spectrometer survey comprised some $900 \mathrm{~km}$ of contour flying with an average speed of 30 knots and a terrain clearance of $30 \mathrm{~m}$. The radiometrically and geologically complex eastern and northern part of the centre were flown with $100 \mathrm{~m}$ contour intervals whereas the rest of the centre, including the adjacent basement, were flown with $200 \mathrm{~m}$ contour intervals.

The radiometric survey outlined several extensive zones of highly radioactive alkaline rocks with maximum values of $150 \mathrm{ppm} \mathrm{eU}$ and $400 \mathrm{ppm}$ eTh. These radioactive anomalous zones are underlain by the microsyenite suite and the texturally and mineralogically heterogeneous medium-grained syenite, most of which is tentatively classified as belonging to the SM 1 syenite unit. The reddish brown colour due to hematite is a diagnostic feature of all the radioactive rocks.

A preliminary evaluation of the airborne radiometric results indicates that the enrichment of the radioactive elements increases upwards because the radioactivity is highest in south-east and north-east Motzfeldt. This suggests that the radioactive elements migrated upwards and were trapped by the roof zone of the intrusion. This is well demonstrated by the follow-up on a minor anomalous zone with a maximum of $65 \mathrm{ppm}$ eU and $60 \mathrm{ppm}$ eTh south 
of Geologfjeld in north-east Motzfeldt. The anomaly here is caused by uranium enrichment at the very top of the microsyenite sequence. The gamma-spectrometer assays of the samples from this 10 to $15 \mathrm{~m}$ wide, $2 \mathrm{~km}$ long zone, range from 250 to $1200 \mathrm{ppm}$ eU and 70 to $400 \mathrm{ppm}$ Th.

The size of these areas of high radioactivity indicates that the possibility of finding zones of uranium enrichment with economic potential is good. In addition, niobium, tantalum and rare earth elements are known to be associated with this uranium in quantities sufficient to warrant further exploration (Tukiainen, 1981).

Molybdenite was also found associated with microsyenite veins, in a loose block of lamprophyre $($ c. $100 \times 150 \times 80 \mathrm{~cm}$ in size $)$ in south-east Motzfeldt. Whether this molybdenum enrichment has any economic interest remains to be investigated.

\section{Uranium occurrences in the Migmatite Complex}

Uranium occurrences in the Kap Farvel - Lindenows Fjord region. The most interesting find of the summer was at locality $\mathrm{N}$ (figs 21,23) in the Kap Farvel - Lindenows Fjord region where there are some particularly high gamma-spectrometer anomalies in the reconnaissance work from 1979. A sizeable uranium mineral occurrence of over $125 \mathrm{~m}$ in length and width from 1 to $5 \mathrm{~m}$ was discovered in meta-arkose rafts and xenoliths in rapakivi granite. The radioactivity does not extend beyond the xenoliths and there does not seem to

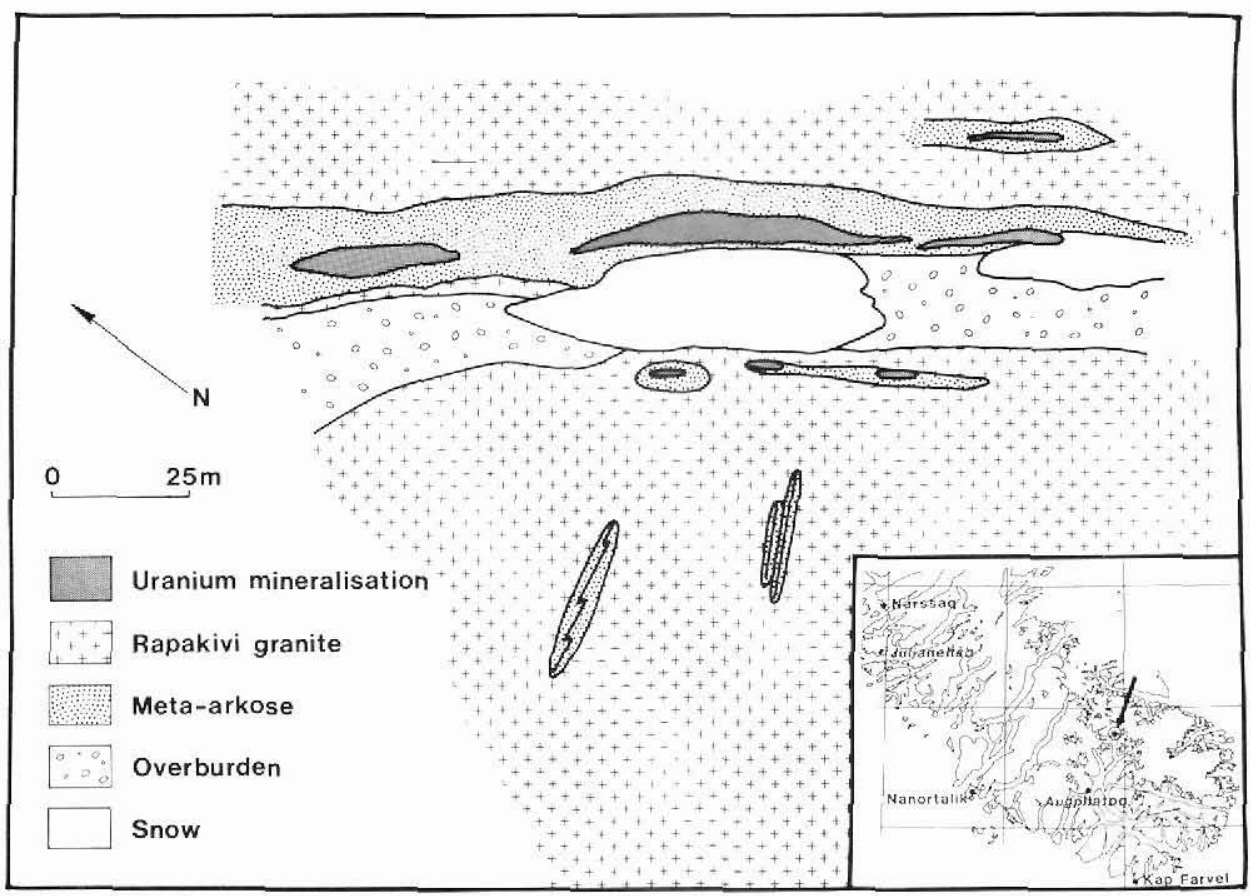

Fig. 23. Sketch map illustrating the geology and extent of the radioactivity of the uranium occurrence (loc. N, fig. 21) in the Migmatite Complex. 
be any relation between the uranium and the surrounding granite (fig. 23). Grab samples vary from $2.8 \%$ to $1.0 \% \mathrm{U}$ and, judging from the radioactivity, mineable thicknesses of over $1 \mathrm{~m}$ may grade from $0.3 \%$ to $1.0 \%$. The thorium content of these mineral occurrences is very low and is comparable with that of the uraniferous neosome discovered in the Tasermiut area (Nielsen \& Tukiainen, 1981), and similar conclusions can be drawn that the uranium is syn-sedimentary on the premise that $\mathrm{U}-\mathrm{Th}$ partitioning only takes place below the temperature of $300^{\circ} \mathrm{C}$.

The implications of this finding are that the supracrustal units throughout the Migmatite Complex, especially where there are radiometric or geochemical anomalies, are favourable for uranium mineralisation and should be prospected in detail. The area is large and the chances of finding other equally promising showings, are good. Very high radioactivity readings have already been recorded from a cliff face at locality $\mathbf{M}$ (fig. 21) but it was impossible to land with a helicopter to take samples.

This uranium was discovered using helicopter-borne scintillometric equipment. The good exposure in the mountainous terrain and the fact that the supracrustal units tend to overly the granite and therefore occur at high altitudes, favour this method of exploration.

\section{Uranium occurrences in the Granite Zone}

Prospecting for veins and other uranium mineral occurrences was concentrated in areas not already followed up in 1980, in particular the nunataks north of Bredefjord, Johan Dahl Land, and the Vatnaverfi peninsula by ground scintillometry, stream-water and stream-sediment sampling. In addition detailed prospecting at Puissataq on the Igaliko peninsula (figs. 21, 24, loc. F) revealed three small pitchblende veins. Detailed mapping was carried out there to evaluate these showings and to determine the usefulness of electromagnetic geophysical methods for locating buried uraniferous structures (Nyegaard \& Thorning, this report).

Uranium occurrences in the nunataks north of Bredefjord and in Johan Dahl Land. There were a number of extremely interesting high uranium values from the gamma-spectrometer results, as well as the geochemical data over the nunataks north of Bredefjord and in Johan Dahl Land. At one of these anomalies (figs. 21, 24, loc. A) numerous uraniferous gneiss boulders and blocks associated with meta-rhyolite and meta-arenite were found. The grade of samples of these uraniferous boulders, some of which contained visible pitchblende and secondary uranium minerals, range from $1-10 \% \mathrm{U}$. Unfortunately early snow made it impossible to map their exact source but, since they were widely distributed below a steep cliff face of the same rock types, they presumably are derived from there. In Johan Dahl Land (figs. 21, 24, loc. B) uraniferous meta-arenite was found associated with meta-rhyolite. The uranium is relatively low grade $(100 \mathrm{ppm})$ but was in a disseminated mineral in the host rock associated with iron oxide, and not in a vein. Both these showings, like those in the Migmatite Complex, lack associated thorium which would be expected if they were derived from granitic or metamorphic processes.

There seems every reason, therefore, to believe that these uranium occurrences are of syn-sedimentary origin, and that they were already present in the overlying supracrustal units before their metamorphism and intrusion by the granite. These findings are the first indications that uranium occurred in the rocks of the Granite Zone prior to the Gardar and 


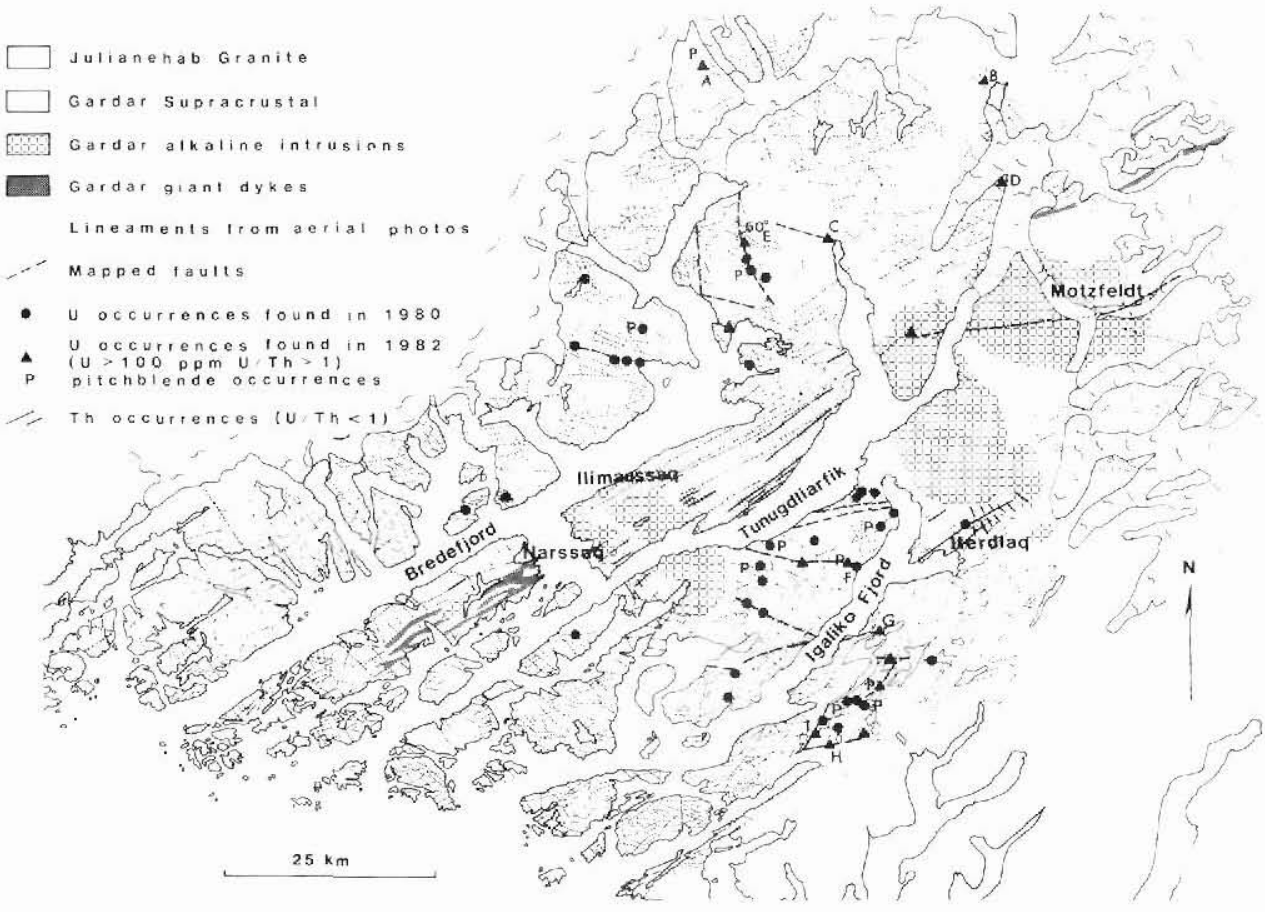

Fig. 24. Uranium occurrences in the Granite Zone.

gives support to the hypothesis that uranium may have been redistributed by the hydrothermal activity related to Gardar magmatic events and deposited in the veins.

Uranium occurrences on the Vatnaverfi peninsula. Considerable efforts were spent on exploring the Vatnaverfi peninsula this season (fig. 21). This was based firstly on the hypothesis that the high mobility of uranium would favour its deposition further from the heat sources (i.e. the Gardar alkaline intrusions) for the hydrothermal activity, secondly because of the high geochemical anomalies in both the stream waters and the stream sediments and the structural conditioning which is similar to the rest of the Granite Zone. However, exploration is hampered in this area by the lack of outcrop due to vegetation covered overburden which is particularly thick along the lineaments which would be expected to host mineral occurrences.

The results of prospecting with scintillometers show that there are numerous radioactive mineral occurrences in this area most of which are uranium dominated and associated with the faults and fractures. Some 45 localities were found which had over $100 \mathrm{ppm} U$ in anomalous radioactive rock samples. Some of these have been shown on the accompanying map (fig. 24). The three most interesting showings (fig. 24, loc. G, H, I) contain minor amounts of pitchblende. Radioactivity along the ENE-trending structure ( $G$ ) can be traced for almost $3 \mathrm{~km}$ with values up to $800 \mathrm{ppm} \mathrm{U}$ at some localities and must be considered a very good prospect. The radioactive showings $(\mathrm{H})$ trend in an $\mathrm{E}-\mathrm{W}$ direction and tend to be 
associated with small fractures rather than in the main lineament. The radioactive showings (I) also occur in the minor fractures along the main lineament rather than the lineament itself. Another interesting feature of the radioactive showings along this structure is that the $\mathrm{U} / \mathrm{Th}$ ratios are very erratic and some samples are dominated completely by Th. This suggests that the assumption that the mineralising fluids were relatively cool in this area may be a little simple. These mineral showings are dominated by siliceous and hematitic material along with quartz and carbonate veining with minor amounts of fluorite and disseminated sulphides similar to those found elsewhere in the Granite Zone.

\section{Conclusions}

The main conclusions that can be drawn from these results are that South Greenland is definitely a part of a uranium geochemical province and that the potential for locating economically mineable uranium deposits is very high.

The increase in both the number and size of the anomalies in the Motzfeldt Centre confirms the already stated mineral potential there. The detailed geological mapping and gamma-spectrometer survey will also prove to be very interesting from the purely geological point of view.

The syn-sedimentary uranium occurrences found in the Migmatite Complex demonstrates that all the supracrustal units in the area could be prospected for uranium particularly those zones containing anomalies from the reconnaissance data. The size and grade of the first occurrence to have been found certainly indicate that this area deserves to be on a higher priority than it has been given so far. They are possibly more important than the uranium veins found in the Granite Zone.

Uranium showings in the Granite Zone continue to be found although the surface expression of the veins still tends to be limited in size. The finding of probable syn-sedimentary uranium showings in the pre-Julianehåb Granite supracrustal units not only suggests new targets for mineral exploration in the zone, but also supports the hypothesis that there was uranium in the area prior to Gardar magmatic activity. At least some, if not all, of the uranium which is found in the veins, therefore, may have been derived from this source and simply been redistributed by the hydrothermal activity related to the Gardar events.

The exploration methods to be used should depend on the environment and target.

The exposure in the Motzfeldt Centre is for the most part so good that mapping, sampling and ground gamma-spectrometric surveys are still the most effective méans of evaluation. These could probably be usefully supplemented by geophysical (VLF and magnetometer) surveys in order to elucidate the structure and locate possible sulphide occurrences prior to any drilling.

In the Migmatite Complex where the outcrop is good, relief is extreme, access is poor and the showings are in the supracrustals which tend to outcrop at high altitudes. Detailed gamma-spectrometer flying with a helicopter would be the most effective way of locating the occurrences. The same method could be used in the well exposed nunataks and at high altitudes in the Granite Zone where the syn-sedimentary showings appear to be preferentially located.

The uranium veins in the faults and fractures, which cannot be detected by gamma-spectrometer from the air because they are usually covered by overburden, should be explored in the first place by a structural analysis using all available imagery. This should be followed up 
by a detailed water sampling programme to locate the uraniferous structures prior to ground geophysical methods and prospecting with ground scintillometers.

\section{References}

Armour-Brown, A., Tukiainen, T. \& Wallin, B. 1981: Uranium districts in South Greenland. Rapp. Grønlands geol. Unders. 105, 51-55.

Emeleus, C. H. \& Harry, W. T. 1970: The Igaliko nepheline syenite complex. General description. Bull. Grønlands geol. Unders. 85 (also Meddr Grønland 186,3) 116 pp.

Jones, A. P. 1981: The petrology and structure of the Motzfeldt Centre, South Greenland. Unpubl. PhD. thesis, University of Durham.

Nielsen, B. L. \& Tukiainen, T. 1981: Uranium-bearing metasediment and granite in the Tasermiut area, South Greenland. Rapp. Grønlands geol. Unders. 105, 47-51.

Tukiainen, T. 1981: Preliminary results of the geological and radiometric reconnaissance in the Motzfeldt Centre of the Igaliko Complex. Unpubl. intern. GGU rep., $27 \mathrm{pp}$.

\section{Geophysical and geological field work on fault structures at the Igaliko peninsula, South Greenland}

\section{Per Nyegaard and Leif Thorning}

Uranium exploration carried out in South Greenland by the Syduran project in the last few years (Armour-Brown et al., 1981) has indicated that certain major E-W fault structures are features worthy of attention in this connection. During August 1982 geological and geophysical field work was carried out $10 \mathrm{~km}$ south-south-east of Igaliko (fig. 25) around a fault zone which had earlier given indications of the presence of uranium mineral occurrences.

The object of the geological work was to map the surface within the geophysical grid and to make a gamma-radiation survey of the area. Pitchblende veins, found in connection with geochemical prospecting, were traced by trenching and were sampled.

The object of the geophysical work was firstly to evaluate the usefulness of various electromagnetic methods for locating and mapping the structures in the Julianehåb granite which contain uranium minerals and secondly to evaluate the extent of the known uranium mineral occurrences. Logistic support was supplied by the Syduran project base camp at Dyrnes.

\section{Geology}

The area investigated is underlain by the Ketilidian Julianehåb granite (1810-1770 m.y.; Van Breemen et al., 1974). During the Gardar period (1330-1150 m.y.; Emeleus \& Upton, 